\title{
Experimental Investigations of Mechanical properties on Micro silica (Silica Fume) and Fly Ash as Partial Cement Replacement of High Performance Concrete
}

\author{
Magudeaswaran $\mathrm{P}^{1}$, Eswaramoorthi $\mathrm{P}^{2}$ \\ ${ }^{I}$ (Department of Civil Enguneering, Sri Ramakrishna Institute of Technology, TamilNadu, India) \\ ${ }^{2}$ (Department of Civil Enguneering, Kumaraguru College of Technology, TamilNadu, India)
}

\begin{abstract}
The Now a day, we need to look at a way to reduce the cost of building materials, particularly cement is currently so high that only rich people and governments can afford meaningful construction. Studies have been carried out to investigate the possibility of utilizing a broad range of materials as partial replacement materials for cement in the production of concrete. This study investigated the strength properties of Silica fume and fly ash concrete. This work primarily deals with the strength characteristics such as compressive, Split tensile and flexural strength. High performance concrete a set of 7 different concrete mixture were cast and tested with different cement replacement levels $(0 \%, 2.5 \%, 5 \%, 7.5 \%, 10 \% 12.5 \%$ and $15 \%)$ of Fly ash (FA) with silica fume (SF) as addition (0\%,5\%,10\%,15\%,25and 30\%) by wt of Cement and/or each trial super plasticizer has been added at constant values to achieve a constant range of slump for desired work ability with a constant water-binder ( $w / b)$ ratio of 0.30.Specimens were produced and cured in a curing tank for $3,7,14$ and 28 days. The cubes were subjected to compressive strength tests after density determination at 3,7,14 and 28 days respectively. The chemical composition and physical composition of micro silica, FlyAsh and cement were determined. The density of the concrete decreased with increased in percentage of micro silica and Fly ash replacement up to 15\%. Increase in the level of micro silica fume and Fly ash replacement between $30 \%$ to $45 \%$ led to a reduction in the compressive strength of hardened concrete. This study has shown that between 15 to $22.5 \%$ replacement levels, concrete will develop strength sufficient for construction purposes. Its use will lead to a reduction in cement quantity required for construction purposes and hence sustainability in the construction industry as well as aid economic construction.
\end{abstract}

Keywords: Durability, Fly Ash, High performance Concrete, Silica Fume/Micro Silica, Density, water absorption

\section{INTRODUCTION}

It was observed and noted that since decade of years that the cost of building materials is currently so high that only corporate organizations, individual, and government can afford to do meaningful construction. Waste can be used as filler material in concrete, admixtures in cement and raw material in cement clinker, or as aggregates in concrete (Olutoge, 2009). Ordinary Portland cement (OPC) is acknowledged as the major construction material throughout the world. The production rate is approximately 2.1 billion tons per year and is expected to grow to about 3.5 billion tons per year by 2015 (Coulinho, 2003). According to Adepegba (1989), the annual cement requirement is about 8.2 million tones and only 4.6 million tones of Portland cement are produced locally. The balance of 3.6 million tonnnnes or more is imported. If alternative cheap cement can be produced locally, the demand for Portland cement will reduce. The search for suitable local materials to manufacture pozzolana cement was therefore intensified (Adepegba, 1989). Most of the increase in cement demand could be met by the use of supplementary cementing materials, in order to reduce the green gas emission ( Bentur, 2002).

Industrial wastes, such as silica fume, blast furnace slag, fly ash are being used as supplementary cement replacement materials and recently, agricultural wastes are also being used as pozzolanic materials in concrete (Sensale, 2006). When pozzolanic materials are incorporated to concrete, the silica present in these materials react with the calcium hydroxide released during the hydration of cement and forms additional calcium silicate hydrate $(\mathrm{C}-\mathrm{S}-\mathrm{H})$, which improve durability and the mechanical properties of concrete (Igarashi et al, 2005).

High strength and high performance concrete are being widely used throughout the world and to produce them, it is necessary to reduce the water binder ratio and increase the binder content. High strength concrete means good abrasion, impact and cavitations resistance. Using high strength concrete in structures today would result in economical advantages. In future, high range water reducing admixtures (Super plasticizer) will open up new possibilities for use of these materials as a part of cementing materials in concrete to produce very high strengths, as some of them are make finer than cement. The brief literature on the study has 
been presented in following text. (Hooten RDC, 1993) investigated on influence of silica fume replacement of cement on physical properties and resistance to sulphate attack, freezing and thawing, and alkali silica reactivity. He reported that the maximum 28 days compressive strength was obtained at $15 \%$ silica fume replacement level, at a W/C ratio of 0.35 with variable dosages of HRWRA. (Prasad et al, 2003), has undertaken an investigation to study the effect of cement replacement with micro silica in the production of high - strength concrete. (Yogendran et al, 1987) investigated on silica fume in high - strength concrete at a constant water binder ratio $(\mathrm{w} / \mathrm{b})$ of 0.34 and replacement percentages of 0 to 25 , with varying dosages of HRWRA. The maximum 28 day compressive strength was obtained at $15 \%$ replacement level. (Lewis et al, 2001) presented a broad overview on the production of micro silica effect of standardization of micro silica concrete both in the fresh and hardened state. (Bhanja et al, 2 003) reported and directed towards developing a better understanding of the isolated contributions of silica fume concrete and determining its optimum content. Their study intended to determine the contribution of silica fume on concrete over a wide range of w/c ratio ranging from 0.26 to 0.42 and cement replacement percentages from 0 to 30 . (Tiwari et al, 2000) presented a research study carried out to improve the early age compressive strength of Portland slag cement (PSC) with the help of silica fume.

High performance concrete has been used more widely in recent years due to the increasing demand for durable concrete in an attempt to extend in service life and reduce maintenance cost of concrete structures. The requirements may involve enhancements of characteristics such as placement and compaction without segregation, long-term mechanical properties, early age strength, toughness, volume stability, or service life in severe environments. High performance concrete incorporation silica and fly ash as pozzolanic mineral admixture is being increasingly used in the construction of structures for large projects. High performance concrete each commonly available in metropolitan areas. Because of superior mechanical properties and the significant economic savings offered by high performance concrete.

Mix design of high performance concrete is complex, because it includes more ingredients like supplementary cementations materials such as a fly ash (FA), micro silica (MS) ground granulated blast furnace slag (GGBFs), metakeoline and super plasticizers. The use of mineral admixture such as a fly ash, silica fume and GGBF slag add strength and durability to concrete. High performance concrete provides enhanced properties in structural precast-concrete, including elevated tensile and compressive strength, and a boosted stiffness. The high performance concrete usually contains both pozzolanic and chemical admixtures. Hence, the rate of hydration of cement and the rate of strength development in HPC is quite different form that of conventional cement concrete (CCC).

\section{Materials And Methods}

The methodology adopted comprised of both preliminary and experimental investigations carried out using the study material and these are presented as follows:

\subsection{Preliminary Investigations}

For the preliminary investigations, micro silica, Fly ash and cement was subjected to physical and chemical analyses to determine whether they are in compliance with the standard used. The experimental program was designed to investigate silica fume and Fly ash as partial cement replacement in concrete. The replacement levels of cement by silica fume and Fly ash are selected as $(0 \%, 2.5 \%, 5 \%, 7.5 \%, 10 \% 12.5 \%$ and15\%) and $(0 \%, 5 \%, 10 \%, 15 \%, 25$ and $30 \%)$ by weight t of Cement for standard size of cubes. The specimen of standard cubes $(150 \times 150 \times 150 \mathrm{~mm})$, cylinders $(150 \mathrm{~mm}$ diameter $300 \mathrm{~mm}$ height), and prism $(100 \times 100 \times 500 \mathrm{~mm})$ was casted for compression, Split tensile strength and flexure test. The specimens were casted with M60 grade concrete with different replacement levels of cement. Samples was casted and put in curing tank for 3, 7, 14, and 28 days and density of the cube, and compressive strength, split tensile strength, Flexural strength were determined and recorded down accordingly. The other materials used are listed as follow:

\subsection{Cement}

Ordinary Portland cement (OPC) conforming to Indian standard code IS 8112-1995 was used.

\subsection{Aggregates}

There are the inert filler in the concrete mixture which constitute between $70-75 \%$ by volume of the whole mixture. Graded river sand passing through $1.18 \mathrm{~mm}$ sieve with fineness modulus of 3.05 and specific gravity of 2.35 was used as fine aggregate $(\mathrm{Fa})$. It was clean and free from organic material and clay. Locally available crushed granite aggregate, passing through $12.5 \mathrm{~mm}$ sieve while being retained on $4.75 \mathrm{~mm}$ sieve with the fineness modulus of 4.03 and specific gravity of 2.88 (conforming to IS 383-1970) was used as coarse aggregate $(\mathrm{Ca})$ and contained only so much fine materials as was permitted for various sizes in the specification. 


\subsection{Water}

The water used for the study was free of acids, organic matter, suspended solids, alkalis and impurities when present may have adverse effect on the strength of concrete Potable water with PH value of 7.0 confirming to IS 456-2000 was used for making concrete and curing this specimen as well.

\subsection{Silica Fume}

The Silica fume obtained from the M/s ELKEM Pvt Ltd, Bombay confirming to ASTM C1240 was used for this study, Its physical and chemical properties were given in Table 1.

\subsection{Fly Ash}

Fly ash (FA) obtained from Thermal power plant, Mettur Salem district, Tamilnadu state, India confirming to IS:3812-1981 used in mineral admixture in day powder form the physical and chemical properties were given Table 1.

\subsection{Chemical admixtures}

Superplasticisers (SP) or high range water reducing admixtures are an essential component of HPC. Conplast SP 430 was used as superplasticiser (conforming to IS: 9103:1999).

\subsection{Blended cement}

SF and FA blended cements were prepared by replacing OPC with combination of SF and FA blended cement were prepared by replacing OPC with different amount of SF+FA by weight of cement). The blended cement was prepared in dry condition. The mixtures were thoroughly homogenized and kept in polythene bottles.

\subsection{Mix proportions and casting of High performance concrete specimens}

Numbers of attempts were made in laboratory to get optimum mix proportion to produce M60 grade HPC without segregation and bleeding with satisfying the properties both in fresh and harden states. For this study totally seven HPC mixes were prepared with a water to binder (W/(C+SF+FA) ratio of 0.29 with $2 \%$ of superplasticiser. The mix proportions are presented in Table 1.

The HPC was mixed for 5 minutes in laboratory drum mixer. For all mixes, nine cube specimens of $150 \mathrm{~mm}$ size were cast from each mix for compressive strength testing. Three cylindrical specimens of $150 \mathrm{~mm}$ diameter and $300 \mathrm{~mm}$ height were also cast from each mix for determining the splitting tensile strength. Before compression test, all specimens were tried and used for ultrasonic pulse velocity test. After casting, all the specimens were left covered in the casting room for 24 hours. The specimens were demoulded and transferred to moist curing room until the time of testing.

\subsection{Fresh state properties of HPC} workability.

Slump flow, compaction factor test and Flow table test were performed in the laboratory to find

\subsection{Compressive strength of HPC}

Compressive strength combination of SF and FA blended cement HPC cube was determined as per IS 9013-1997 after 7, and 28 of moisture curing.

\subsection{Splitting tensile strength of HPC}

Splitting tensile strength test was conducted on combination of SF and FA blended HPC cylinder as per IS 5816-1999 after 28 days of moisture curing.

\subsection{Flexural strength of HPC}

Flexural strength test was conducted on combination of SF and FA blended HPC prism of size $100 \mathrm{~mm} \times 100 \mathrm{~mm} \times 500 \mathrm{~mm}$ were tested as per IS 516-1959 after 28 days of moisture curing. The load was applied through two similar rollers mounted at one third points of the supporting span. The load was applied without shock until the failure occurs. Modulus of rupture was evaluated at age 28 days. 


\section{III.}

\subsection{Compressive strength Test on cubes}

\section{Results And Discussion}

The cube compressive strength results of High Performance Concrete mixes at the ages of 3, 7, 14, 28 days are presented in table 3 . The development of compressive strength of M60 grade of HPC mixes containing $0,2.5,5,7.5,10,12.5$ and 15 percent of silica fume and $0,5,10,15,20,25,30$ percent of fly ash at the various stages are plotted in the form of graphs are shown in figure 5.1.According to results combination of MK and FA show higher compressive strength than normal HPC (HPC with $0 \%$ replacement of cement). It is interesting to see that the compressive strength of HPC with 15\% FA was higher than that of the Controlled mix. This result shows the benefit of using FA in combination with SF to produce HPC with higher replacement of cement about $15 \%(\mathrm{FA} 10 \%+5 \% \mathrm{SF})$.

\subsection{Splitting tensile strength of HPC}

The splitting tensile strength combination of FA and SF blended HPC after 28 days curing are shown in Fig. 5.2. It can be clearly seen that the splitting tensile strength value increases with the combination of SF and FA up to $22.5 \%(7.5 \% \mathrm{SF}+15 \% \mathrm{FA})$ the splitting tensile strength is higher than the controlled mix. But Cement replacement beyond $30 \%(\mathrm{SF}+\mathrm{FA})$ there is a decrease in splitting tensile strength for 28 days curing period to the controlled mix.

\subsection{Flexural strength of HPC}

The Flexural strength combination of FA and SF blended HPC after 28 days curing are shown in Fig. 5.3.It can be clearly seen that the flexural strength value increases with the combination of SF and FA up to $22.5 \%(7.5 \% \mathrm{SF}+15 \% \mathrm{FA})$ the flexural strength is higher than the controlled mix. But Cement replacement beyond $30 \%(\mathrm{SF}+\mathrm{FA})$ there is a decrease in strength for 28 days curing period to the controlled mix. The flexural strength is found to increase by the addition of the fine grained particle due to increase in bond strength as they form a rigid structure comparatively. The theory behind this is that when these pozzolans are added to the cement, they react with them and forms a uniform paste of concrete and increase the binding capacity of concrete. This phenomenon increases the flexural strength of concrete.

\section{TABLES}

Table 1: Physical and Chemical Properties of Cement and Admixtures

\begin{tabular}{|l|c|c|c|}
\hline \multicolumn{4}{|c|}{ Physical and Chemical Properties of Cement and Admixtures } \\
\hline Property/ Composition & Cement & Fly Ash & Silica Fume \\
\hline Specific Gravity & 3.15 & 2.00 to 2.05 & 2.2 \\
\hline Standard Consistency & $30.00 \%$ & - & - \\
\hline Initial Setting time (Min) & 104 & - & - \\
\hline Final Setting Time (Min) & 220 & - & Powder form \\
\hline Physical Form & - & Powder form & - \\
\hline Class & - & F & $90-96 \%$ \\
\hline Chemical Composition & & & $0.5-0.8 \%$ \\
\hline Silicon Dioxide (SIO2 $)$ & $19.65 \%$ & $23.04 \%$ & $0.2-0.8 \%$ \\
\hline $\begin{array}{l}\text { Aluminium Oxide } \\
\text { (Al2O3 ) }\end{array}$ & $5.65 \%$ & & $0.1-0.5 \%$ \\
\hline Ferric Oxide (Fe2O3 ) & $5.40 \%$ & $4.5-4.8 \%$ & $0.5-1.5 \%$ \\
\hline Calcium Oxide (CaO) & $61.55 \%$ & $3.84 \%$ & $2.82 \%$ \\
\hline Magnesium Oxide (MgO) & $0.91 \%$ & & \\
\hline
\end{tabular}

Table .2 Basic Properties of Aggregates

\begin{tabular}{|c|c|c|}
\hline \multicolumn{3}{|c|}{ Basic Properties of Aggregates } \\
\hline Property & Fine Aggregate & Coarse Aggregate \\
\hline Fineness Modulus & 3.04 & 4.03 \\
\hline Specific Gravity & 2.35 & 2.88 \\
\hline
\end{tabular}


Experimental investigations of mechanical properties on micro silica (silica fume) and fly ash as

Table .3 Compressive strength results

\begin{tabular}{|c|c|c|c|c|c|c|c|}
\hline DAYS & $\begin{array}{l}\text { Controlled } \\
\text { mix }\end{array}$ & $\begin{array}{c}2.5 \% \text { SF\& } \\
5 \% \mathrm{FA}\end{array}$ & $\begin{array}{l}5 \% \text { SF\& } \\
10 \% \text { FA }\end{array}$ & $\begin{array}{c}7.50 \% \text { SF\& } \\
15 \% \mathrm{FA}\end{array}$ & $\begin{array}{c}10 \% \text { SF\& } \\
20 \% \text { FA }\end{array}$ & $\begin{array}{c}12.50 \% \mathrm{SF} \& \\
15 \% \mathrm{FA}\end{array}$ & $\begin{array}{c}15 \% \text { SF\& } \\
30 \% \mathrm{FA}\end{array}$ \\
\hline 3 & 37.33 & 41.22 & 41.63 & 35.25 & 37.18 & 38.22 & 35.7 \\
\hline 7 & 45.18 & 49.18 & 50.51 & 41.18 & 40.88 & 40.29 & 42.51 \\
\hline 14 & 58.89 & 52.29 & 53.18 & 50.37 & 50.07 & 47.4 & 44.74 \\
\hline 28 & 54 & 59 & 61.5 & 60 & 54.22 & 51 & 51.4 \\
\hline
\end{tabular}

Table .3 Split Tensile test results

\begin{tabular}{|c|c|c|c|}
\hline S.NO & $\begin{array}{c}\text { FLY ASH CONTENT } \\
\%\end{array}$ & SILICA FUME \% & $\begin{array}{c}\text { RESULT } \\
\left(\mathrm{N} / \mathrm{mm}^{2}\right)\end{array}$ \\
\hline 1 & 0 & 0 & 3.21 \\
\hline 2 & 5 & 2.5 & 3.30 \\
\hline 3 & 10 & 5 & 3.25 \\
\hline 4 & 15 & 7.5 & 3.60 \\
\hline 5 & 20 & 10 & 2.59 \\
\hline 6 & 15 & 12.5 & 2.64 \\
\hline 7 & 30 & 15 & 2.78 \\
\hline
\end{tabular}

Table. 4 Flexural Strength test results on beams

\begin{tabular}{|c|c|c|c|c|c|}
\hline S.NO & $\begin{array}{c}\text { FLY ASH } \\
\text { CONTENT } \\
\%\end{array}$ & $\begin{array}{c}\text { SILICA } \\
\text { FUME } \%\end{array}$ & $\begin{array}{c}\text { NO OF } \\
\text { CYLINDERS }\end{array}$ & $\begin{array}{c}\text { CURING } \\
\text { PERIOD } \\
\text { (DAYS) }\end{array}$ & $\begin{array}{c}\text { RESULT } \\
\mathrm{N} / \mathrm{mm}^{2}\end{array}$ \\
\hline 1 & 0 & 0 & 3 & 28 & 9.41 \\
\hline 2 & 5 & 2.5 & 3 & 28 & 9.91 \\
\hline 3 & 10 & 5 & 3 & 28 & 7.15 \\
\hline 4 & 15 & 7.5 & 3 & 28 & 11 \\
\hline 5 & 20 & 10 & 3 & 28 & 7.67 \\
\hline 6 & 15 & 12.5 & 3 & 28 & 6.83 \\
\hline 7 & 30 & 15 & 3 & 28 & 6.75 \\
\hline
\end{tabular}

V. FIGURES

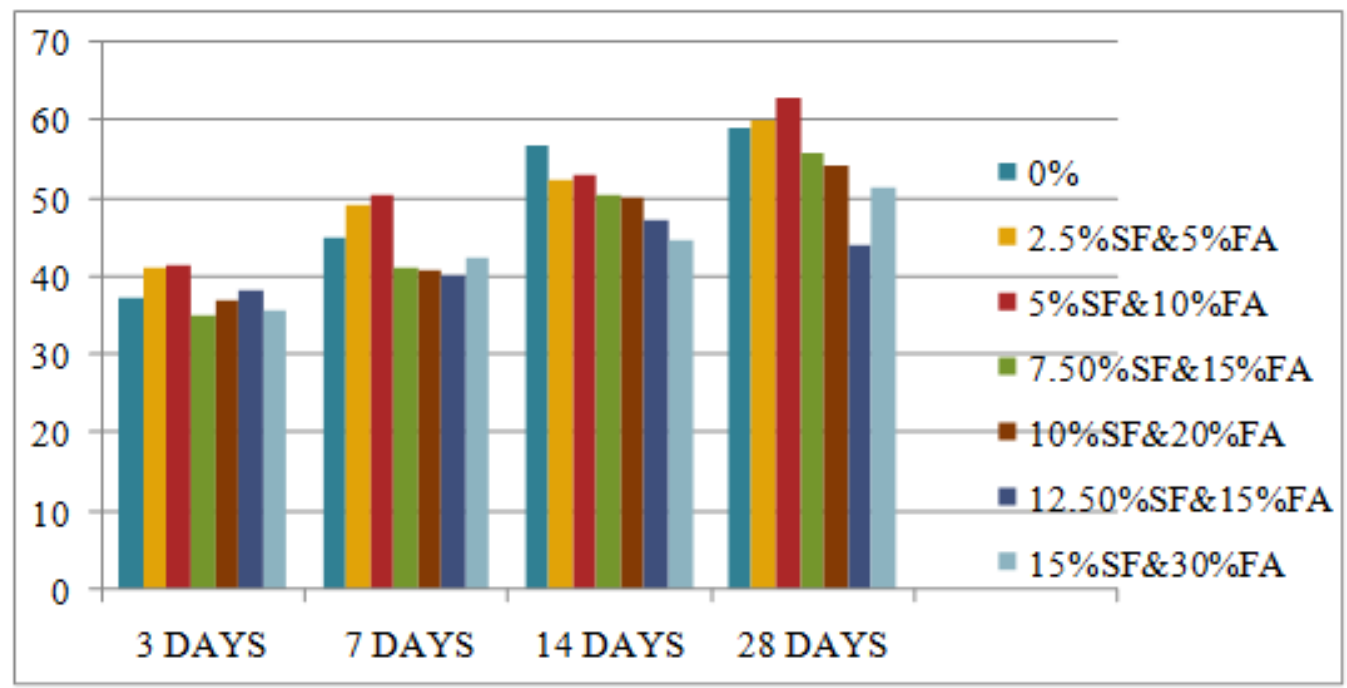

Fig no. 5.1 Relationship between compressive strength of varying SF\&FA replacement levels in $\left(\mathbf{N} / \mathbf{m m}^{2}\right)$. 


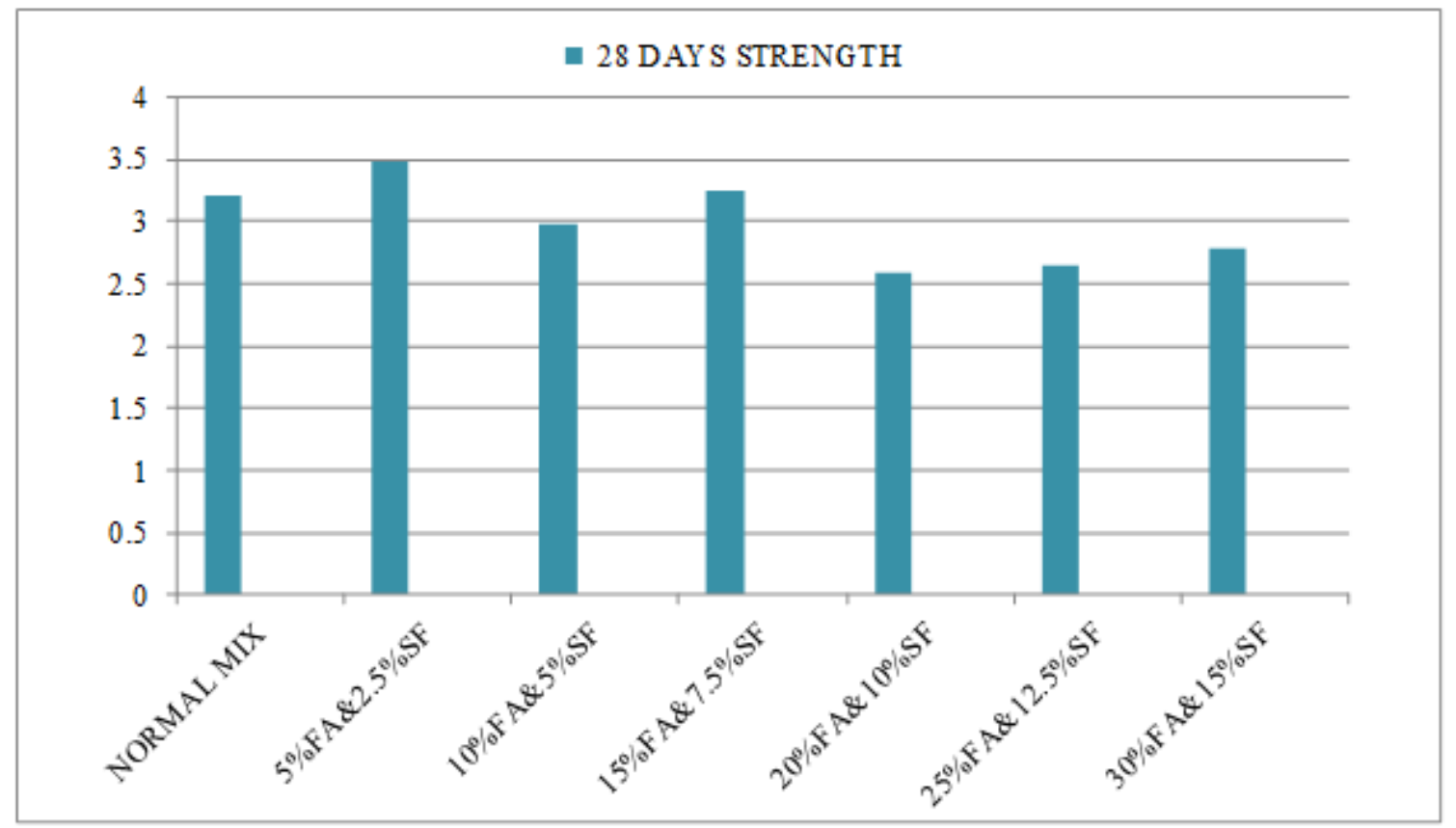

Fig no.5.2 Relationship between Split tensile strength of varying SF\&FA replacement levels in $\left(\mathbf{N} / \mathbf{m m}^{2}\right)$.

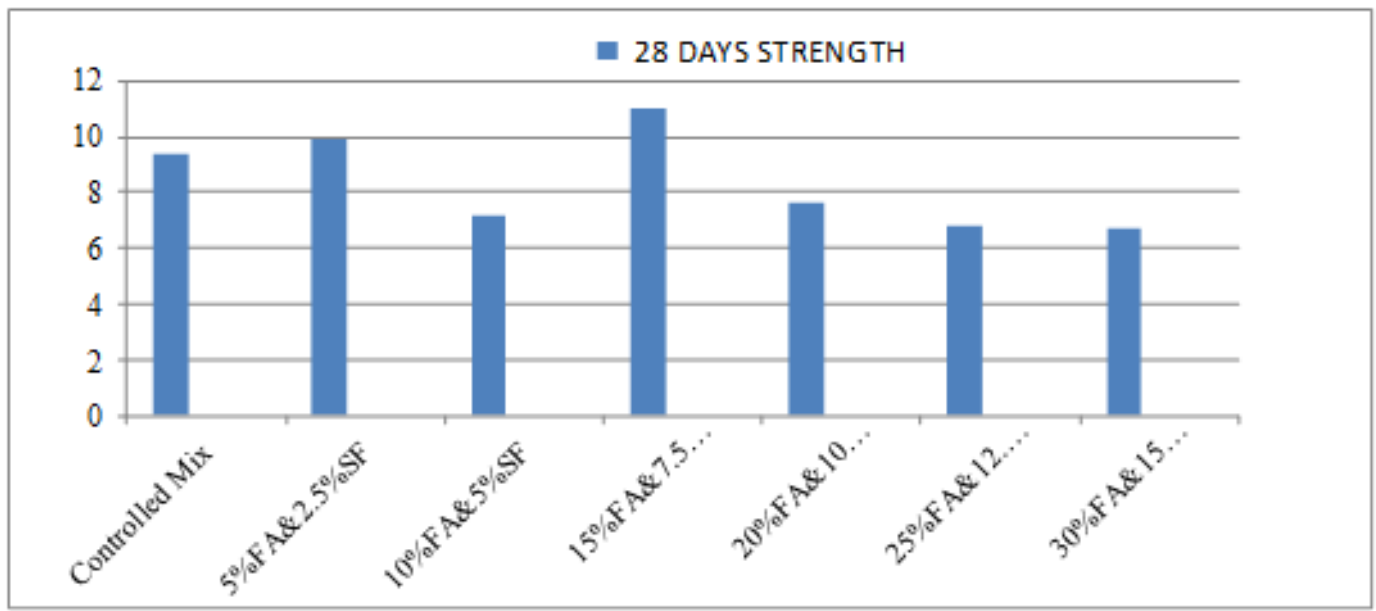

Fig no5.3 Relationship between Flexural strength of varying SF\&FA replacement levels in (N/mm2).

\section{CONCLUSION}

Based on the experimental studies presented in this paper, the following conclusions may be drawn,

Dhe compressive strength is increased by $13.9 \%$ for the replacement of cement by $10 \%$ fly ash and $5 \%$ silica fume mix.

$>$ Split tensile strength is increased by $12.15 \%$ for the replacement of cement by $15 \%$ fly ash and $7.5 \%$ silica fume mix.

$>$ Flexural strength increased by $16 \%$ for the replacement of cement by $15 \%$ fly ash and $7.5 \%$ silica fume mix.

\section{REFERENCES}

[1]. Alireza Mokhtarzadeh, Catherine W.(1995), "High Strenth Concrete: Effects of Materials, Curing and Test Procedures on Short-Term Compressive Strength", PCI Journal, pp. 76-87.

[2]. Chinnaraju K, Subramanian K and Senthil Kumar S R R (2011), "Role of Fly Ash and Silica Fume on Durability Characteristics of High Performance Concrete", International Journal of Advance in Civil Engineering, pp. 17-27.

[3]. Hariharan A R, Santhil A S and Mohan Ganesh G (2011), "Study on Strength Development of High Strength Concrete Containing Fly Ash and Silica Fume", International Journal of Engineering Science and Technology, Vol. 3, pp. 2955-2961. 
[4]. Islam Laskar A and Talukdar S (2008), “A New Mix Design Method For High Performance Concrete”, Asian Journal of Civil Engg. (Building And Housing),Vol. 9,No. 1, pp. 15-23.

[5]. IS 456 (2000), Bureau of Indian Standardplain and Reinforced Concrete-Code of Practice, Fourth Revision.

[6]. IS 10262 (2009), Bureau of Indian Standard-concrete Mix Proportioning guide Lines, first Revision.

[7]. Mullick A K (2007), "Performance of Concrete with Binary and Ternary Cement Blends", the Indian Concrete Journal, pp. 15-22.

[8]. Nataraja M C and Lelin Das (2010), "Concrete Mix Proportioning as per IS 10262:2009-Comparison with IS 10262:1982 and ACI 211.1-91”, The Indian Concrete Journal, pp. 64-70.

[9]. Perumal K and Sundararajan R (2004), "Effect of Partial Replacement of Cement With Silica Fume on The Strength And Durability Characteristics of High Performance Concrete" our World in Concrete and Structures, pp. 397-404.

[10]. Suryawanshi C S (2007), "Structural Significance of High Performance Concrete", The Indian Concrete Journal, pp. 13-16

[11]. Pazhani.K, Jeyaraj.R, "Study on durability of high performance concrete with industrial waste", Applied Technology and Innovation, Vol 2, Issue 2, Aug 2010, pp 19-28.

[12]. Muthupriya, "Experimental study on high performance reinforced concrete column with silica fume and fly ash as admixtures", Journal of Structural Engineering, Vol 38, No.1, April-May 2011, pp- 46-59 